\title{
CHINESE MULTINATIONALS: HOST COUNTRY FACTORS \\ AND FOREIGN DIRECT INVESTMENT LOCATION
}

\author{
Diego Quer \\ Enrique Claver \\ Laura Rienda \\ Department of Management \\ University of Alicante, Spain
}

\begin{abstract}
The study of Chinese multinationals (MNEs) is becoming one of the most promising research topics in the international business literature. After outlining the distinctive characteristics of the internationalization process of Chinese MNEs, this chapter analyzes the influence of various host country factors on the location of Chinese outward foreign direct investment (FDI). From a sample of 189 outward FDI decisions made by 35 mainland Chinese firms in 63 countries, our results show that host market size and the existence of overseas Chinese in the host country are positively associated with the number of Chinese FDIs. However, greater difficulty in doing business and host country political risk have no effect.
\end{abstract}




\section{INTRODUCTION}

Until recently, China has been widely known as a destination of FDI. However, since 2002, Chinese outward FDI has increased substantially. As a result, Chinese outward FDI multiplied by four from 2005 to 2009, and China ranked as the sixth largest global outbound investor in 2009 (UNCTAD, 2010). It is also estimated that by the end of 2009 there were around 13,000 businesses with Chinese capital in 177 countries (MOFCOM, 2010). Table 1 shows the evolution of Chinese outward FDI flows and stocks.

"Table 1 goes here"

Chinese firms listed in Fortune Global 500 have been key players in the main Chinese cross-border mergers and acquisitions (M\&As) carried out since 2002. The takeover of the Swiss-Canadian company Addax Petroleum and the partial acquisitions of Repsol YPF Brasil and Syncrude Canada by Sinopec, the acquisition of a 20 percent stake in Standard Bank of South Africa by Industrial and Commercial Bank of China (ICBC) or the takeover of Petrokazakhstan by China National Petroleum corporation (CNPC) are the most outstanding examples. Table 2 reports the largest cross-border M\&As carried out by Chinese companies listed in Fortune Global 500, ranked by transaction value.

"Table 2 goes here"

Research into international business has not been unaffected by this rise of Chinese MNEs. After an initial few years when eminently descriptive papers predominated, recent studies have sought to explore further into certain specific topics, such as the factors that determine Chinese outward FDI location choice (Duanmu, 2011; Duanmu \& Guney, 2009; Kang \& Jiang, 2011; Kolstad \& Wiig, 2011; Pangarkar \& Yuan, 2009; Ramasamy, Yeung \& Laforet, 2011; Yuan \& Pangarkar, 2010). This chapter aims to contribute to this literature by analyzing the influence of various host country factors on the location decisions of Chinese MNEs listed in Fortune Global 500. More precisely, we study how factors such as host 
market size, host country's regulatory framework, political risk and cultural distance affect the number of FDIs in each country. Before that, we provide an overview of the distinctive characteristics of the internationalization process of Chinese MNEs.

\section{THE INTERNATIONAL EXPANSION OF CHINESE MNES: AN OVERVIEW}

\section{Motives of Chinese outward FDI}

Clearly, because China is itself a low-cost production base, cost minimization is not a major objective of Chinese MNEs (Cheng \& Ma, 2007). The main motivations are threefold (Deng, 2004; Hong \& Sun, 2006; Wong \& Chan, 2003; Wu \& Sia, 2002): resource seeking, market seeking and diversification, and strategic asset seeking.

The search for resources, particularly natural resources, has been one of the traditional objectives of Chinese FDI. Until 1991, it was concentrated on Canada and Australia, extending to other countries during the 1990s with an increasing emphasis on fuel and industrial raw materials.

At first, Chinese FDI also often arose from the need to diversify markets and obtain foreign exchange. The establishment of trading subsidiaries promoted Chinese exports. Furthermore, Chinese companies face quantitative restrictions on exports to other countrieseven more severe than for non-Chinese companies-, so manufacturing FDI has been in many cases the solution to continue accessing those markets.

Some major Chinese State-owned enterprises (SOEs) have made FDIs seeking to diversify risks. This strategy has been reinforced by the trade reforms started in the $1980 \mathrm{~s}$, which meant that some companies lost their monopoly in China. One such example is Sinochem, a foreign-trading SOE that held a monopoly over the import and export of oil and chemical fertilizers. As a result of the reforms, Sinochem had to find new lines of business, 
which have transformed it into a diversified company operating in industries such as oil, chemicals, tourism or real estate.

Many Chinese firms have also sought to exploit their comparative advantages in developing areas of Southeast Asia, Africa and Latin America. These are projects in which Chinese firms provide equipment, machinery and raw materials, through which they also contribute to increasing exports from China.

Finally, some Chinese companies, rather than exploit an existing competitive advantage, are seeking to acquire strategic assets abroad. They are looking to access advanced technology and managerial know-how in developed countries. They also invest in developed markets seeking internationally recognized trademarks. One of the most outstanding examples of this is the acquisition of the IBM's PC division by Lenovo.

As a concluding remark on the motivations of Chinese outward FDI, it is worth mentioning a survey carried out by KPMG (2010), where 156 executives of mainland Chinese MNEs reported that the most popular objectives for outbound investment were: geographic growth, building global profile and reputation, diversification strategy and climbing up or going down the value chain.

\section{Facilitators of Chinese outward FDI}

The internationalization of Chinese companies has been favored by factors such as the huge foreign currency reserves accumulated from exports or the knowledge acquired from foreign partners doing business in China (Child \& Rodrigues, 2005; Hong \& Sun, 2006). In any case, the real driving force behind the process has been the Chinese government, which considers the international expansion of Chinese companies as a key element to ensuring the country's economic growth.

The reasons that the Chinese government encourages outward FDI are (Shoham \& Rosenboim, 2009): resource exploration; projects that can promote Chinese exports; overseas 
research and development centers; M\&As that can enhance the international competitiveness of Chinese enterprises and accelerate their entry into foreign markets; and encouraging international growth through outward FDI is considered consistent with China's trade surplus and with the positive gap between savings and investments that characterizes the national accounts.

Outward FDI was first permitted in 1979, but it remained prohibited for private companies until 2003. During that initial period, the internationalization of Chinese companies was tightly controlled by the government (Buckley, Clegg, Cross, Liu, Voss \& Zheng, 2007). In 2002, the Chinese government initiated a "go out" policy, which aimed to boost the international competitiveness of Chinese companies by reducing the obstacles to outward FDI. The setting up of overseas operations by Chinese firms then became one of the official policies for opening up the economy, with the leading role being played by SOEs, which were seen as instruments through which to achieve national objectives (Zhang \& Van den Bulcke, 1996). Since then, the Chinese government has continued to provide incentives for the process: tax relief, credit support, risk-safeguard mechanisms, information service, simplify the process of approval, etc. (Luo, Xue \& Han, 2010). The Chinese government considers that forming large MNEs will help China to become a key player in the global economy. Helping Chinese companies get onto the Fortune Global 500 list has thus become an objective in itself (Hong \& Sun, 2006).

Anyway, FDI by any Chinese firm, either privately or State-owned, requires approval by the Chinese government, in order to ensure that all investments activities conform to government policies and goals. Taking into account this influence, Gugler and Fetscherin (2010) propose a conceptual framework outlining the interests of the government versus the interests of Chinese companies. They suggest that where both interests are high and aligned, it's expected that the scale and the speed in which those investments will be conducted and 
executed to be large and fast. This is the case of market-seeking and strategic asset-seeking investments.

\section{Challenges for Chinese MNEs}

Obviously, the emerging rise of Chinese MNEs is not without problems. As latecomers, they have a disadvantage compared to their Asian and Western counterparts. In particular, the main problems and challenges they must face are the following (Luo \& Tung, 2007; Wu, 2007):

- Due to their limited experience in M\&As, they have yet to demonstrate whether they have the skills required to face post-acquisition difficulties, in particular, those related to cultural differences.

- They lack international experience-in particular, specific market knowledge, which is only acquired through learning by doing.

- They need to improve their product and process innovation-since it is difficult to survive in the long term trusting only to acquisitions for knowledge development.

- The State ownership of many of them makes them vulnerable to political risk in countries where the assets they seek are considered strategic.

- The less developed status of the home stock markets and the lack of transparency derived from their state ties mean their corporate governance is generally weaker.

\section{Foreign market entry modes of Chinese firms}

Chinese companies have mainly employed three routes toward internationalization (Child \& Rodrigues, 2005). The first of these is the original equipment manufacture through joint ventures (JVs) or licenses. It is an inward method of internationalization, i.e. within China itself. It consists of associating with a foreign MNE to obtain modern practices that help to strengthen international competitiveness with a view to eventual outward internationalization. An example of this strategy can be found at Huawei-one of the 
world's leading suppliers of broadband Internet access equipment-, which initially established several JVs with foreign companies.

The second entry mode is acquisition. This has been chosen by large material processing SOEs, which have made major acquisitions to ensure the supply of raw materials. This mode has also been selected by Chinese firms belonging to other industries, with the aim of accessing technology, ensuring R\&D skills or acquiring international branding. Acquisition provides a quick route to these benefits. Some of the abovementioned acquisitions, such as Lenovo's acquisition of the PCs division of IBM, are illustrative of this strategy.

The third route is the organic international expansion, which involves the greenfield establishment of subsidiaries in other countries. The aim in this case tends to be to obtain advantages of differentiation in terms of, for example, adaptation to local needs, although it also facilitates managerial control and the possibilities for global integration. Domestic appliances manufacturer Haier may be deemed one of the best examples of a Chinese company that has gone international mainly along this route.

\section{HOST COUNTRY FACTORS AND CHINESE FDI: HYPOTHESES DEVELOPMENT}

As stated in the introduction section, our empirical research focuses on analyzing the influence of host country factors on the number of Chinese FDIs in each destination country. In this section, we propose a series of hypotheses regarding the impact of host market size, market-supporting institutions, political risk and cultural distance.

\section{Host market size}

Characteristics of the host market are widely recognized factors that affect the flow of FDIs received by a country. Market access is one of the most acknowledge motivation of FDI 
(Duanmu \& Guney, 2009). Empirical evidence has revealed a positive relationship between host market size and FDI inflows (Mascarenhas, 1992; Yu, 1990).

As markets increase in size, so do the opportunities for the efficient utilization of resources and the exploitation of economies of scale and scope via FDI (Buckley et al., 2007). Furthermore, a fast growing economy leads to a high level of aggregate demand for product and stimulates FDI inflows (Kang \& Jiang, 2011). As a result, the larger the market size and the higher the economic growth rate, the more attractive the host country is and the more FDI that is attracted to that country. Thus, we propose that:

Hypothesis 1: The number of Chinese FDIs in a country is positively associated with host market size.

\section{Market-supporting institutions}

Institutional differences are particularly important for MNEs operating in more than one institutional context (Meyer, Estrin, Bhaumik \& Peng, 2009). The formal and informal rules affect not only how a company chooses to enter an economy, but the very decision on whether or not to set up in a particular country.

Institutional factors play an increasingly important role in the location decisions (Zheng, 2009). Institutional changes in FDI regulations can have a major influence on geographic diversification decisions (Peng \& Delios, 2006), and many countries have stepped up their bids to attract FDI by implementing favorable policies for foreign investors.

The strength of a country's institutional framework reduces business costs for foreign companies. In many emerging economies, institutional weakness may exaggerate the asymmetry of information, so companies face greater risks and need to spend more resources to find information (Meyer et al., 2009). In countries with no institutional restrictions, foreign investment companies are not subject to discriminatory policies regarding the percentage of ownership in the subsidiary, access to local resources or having to export part of their 
production. The presence of a favorable institutional framework in the host country can, therefore, be expected to attract FDI. As a result, we can propose that:

Hypothesis 2: The number of Chinese FDIs in a country is positively associated with the strength of market-supporting institutions in the host country.

\section{Political risk}

Another institutional factor that has a strong influence on decisions to enter a certain country is the political environment, and political risk in the host country has taken up much space in the literature. Political risk can be considered alongside any other kind of external influence that affects the company's operations, whether that means the possibility of expropriation or nationalization of the investment, or other government actions or changes in the political and social situation that could have a negative effect on economic activity (Kobrin, 1979; Robock, 1971; Simon, 1984).

The differences in political risk between countries affect the stability of their markets, which affects foreign companies aiming to do business there. The high degree of uncertainty associated with foreign ownership or increased asset exposure in the event of eventual expropriation are some of the factors that can hinder FDI decisions (Brouthers, 2002; Pak \& Park, 2004).

It is to be expected that political risk will be negatively related to FDI, given that MNEs will be more reluctant to invest in countries that are a high risk or have an unstable environment (Buckley et al., 2007; Zheng, 2009). These arguments would therefore suggest that:

Hypothesis 3: The number of Chinese FDIs in a country is negatively associated with rising levels of host country political risk. 


\section{Cultural distance}

Cultural distance refers to possible existing differences in terms of how individuals from different countries observe certain behaviors, which will affect the extent to which working practices and methods can be transferred from one country to another (Hofstede, 1980, 1991). It is another traditional factor in the literature on entry decisions (Chen \& $\mathrm{Hu}, 2002$; Madhok, 1997; Pak \& Park, 2004; Randoy \& Dibrell, 2002): it can lead to additional costs in obtaining information, and disrupt communication processes, as well as making it difficult for the local subsidiary to integrate, for the company's own routines to be applied and for the product to be adapted.

While institutions are crystallizations of culture, culture is the substratum of institutional arrangements (Hofstede, Van Deusen, Mueller, Charles \& The Business Goals Network, 2002). More precisely, culture can be considered part of the environment's informal institutions, which underpin formal institutions (Peng, Wang \& Jiang, 2008). When MNEs enter an institutional environment with a different set of rules, they must meet social expectations to demonstrate social responsibility and build social legitimacy in the host country. The difficulty in attaining this social legitimacy is related to the cultural distance between the country of origin and the host country (Cui \& Jiang, 2009b, 2010). We can therefore expect that:

Hypothesis 4: The number of Chinese FDIs in a country is negatively associated with cultural distance between China and the host country. 


\section{EMPIRICAL RESEARCH}

\section{Data collection}

The sample for this study is made up of outward FDIs made by mainland Chinese companies listed in Fortune Global 500. Overall, 44 different mainland Chinese firms were listed between 2005 and 2010.

The data on each FDI were obtained from news items published on the website of China Daily (www.chinadaily.com.cn), the largest English-language newspaper in China. Having searched all news items covering international operations by each of the 44 companies between January 2002 and December 2010, we identified 35 mainland Chinese firms that had invested abroad during this period. There were 189 FDIs in 63 countries, this being the sample for our study.

\section{Descriptive statistics}

Next we provide some descriptive statistics of our sample. As table 3 shows, the number of Chinese outward FDIs grew substantially since 2004, with the last three years concentrating 107 out of the 189 FDIs covered by our sample, i.e. 56.6\% of the total: 2008 (40 FDIs), 2009 (33) and 2010 (34).

"Table 3 goes here"

Table 4 reports descriptive data for location distribution of our sample. Australia leads the ranking of top destinations, with 17 FDIs, followed by the US (13), Indonesia (11), the UK (10), Canada (9), Russia (7), Singapore (6) and Brazil (5).

"Table 4 goes here"

Table 5 lists the top Fortune Global 500 mainland Chinese firms by outward FDIs. The company that made most FDIs during the period analyzed was China National Petroleum Corporation (CNPC) (25 FDIs), followed by Huawei Technologies (15), Industrial and Commercial Bank of China (ICBC) (14), Sinopec (13), China National Offshore Oil 
Corporation (CNOOC) (12) and Bank of China (10). The top 12 companies listed in table 5 carried out 130 FDIs, representing $68.8 \%$ of the whole sample.

"Table 5 goes here"

\section{Measures}

Dependent variable. The dependent variable in this study is the number of Chinese FDIs made in each country, a figure that was obtained directly from the China Daily website. The mean was 3 FDIs, with a standard deviation of 3.1.

Independent variables. We measured host market size by different indicators related to host country GDP (Buckley et al., 2007; Bunyaratavej \& Hahn, 2007; Duanmu, 2011; Duanmu \& Guney, 2009; Kang \& Jiang, 2011; Kolstad \& Wiig, 2011; Li \& Wu, 2006; Malhotra \& Zhu, 2009). More precisely, by using data from the UN Statistics Division (2010), we considered absolute host-market size (proxied by host-country GDP) and host-market growth (proxied by using the annual percentage increase in GDP). We used log transformation to normalize the distribution of both measures.

The strength of market-supporting institutions in the host country was proxied by the World Bank (2010) ranking on the ease of doing business. This annual report, which covers 183 economies, provides a quantitative measure of regulations for starting a business, dealing with construction permits, registering property, getting credit, protecting investors, paying taxes, trading across borders, enforcing contracts and closing a business. Based on each economy's mean score for these indicators, the World Bank produces a ranking of 183 countries, rated from the easiest country to do business in (1) to the most difficult (183). Previous research, such as the work by Meyer et al. (2009), has used a similar index to proxy the strength of market-supporting institutions.

Based on Buckley et al. (2007), Duanmu (2011) and Duanmu and Guney (2009), host country political risk was proxied by the political risk rating of the International Country Risk 
Guide (PRS, 2010). This rating assigns risk points to a pre-set group of factors, termed political risk components. In every case the lower the risk point total, the higher the risk, and the higher the risk point total the lower the risk. In order to obtain a measure of the relative political risk, we considered the political risk distance between mainland China and each target market.

We used two items to measure cultural distance. First, using the Kogut and Singh (1988) index, we calculated the cultural distance between China and each host country. Second, based on data reported by the Ohio University (2010), we measured the cultural proximity to China using the percentage of ethnic Chinese in the host population (Buckley et al., 2007; Ramasamy et al., 2011). This variable takes value 1 when this percentage is higher than $1 \%$, and zero otherwise.

\section{Results of the empirical research}

The hypotheses were tested using an ordinary least squares (OLS) regression to examine the impact of the independent variables (market size, ease of doing business, political risk and cultural distance) on the number of Chinese FDIs in each host country. Before conducting the regression analysis, we performed a multicolinearity diagnosis, examining the variance inflation factor (VIF) for all the variables. This test measures the extent to which the variances of the coefficients estimated in a regression are inflated when compared to the cases in which the independent variables are not linearly related. High VIF values can become indicators of the existence of multicolinearity. The highest VIF was 2.99 , which is well below 10 , the cutoff point recommended by Neter, Wasserman and Kutner (1985). This allows us to rule out the presence of multicolinearity in our data. Table 6 shows the regression analysis results.

"Table 6 goes here"

The regression equation is statistically significant $(\mathrm{F}=5.08, \mathrm{p}<0.001)$. Hypothesis 1 predicted that host market size was positively associated with the number of Chinese FDIs. 
We obtained support for that hypothesis, but only for absolute host market size $(\beta=0.52, \mathrm{p}<$ 0.01 ), since the positive effect of host market growth was not statistically significant $(\beta=0.40$, $\mathrm{p}>0.1)$

Hypothesis 2 stated that strengthening institutions that make it easier to do business in the host country were positively related to Chinese outward FDI. This hypothesis is not supported $(\beta=0.01, \mathrm{p}>0.10)$. Similarly, hypothesis 3 , which established an inverse relationship between political risk in the host country and the number of Chinese FDIs, is also not supported $(\beta=-0.02, \mathrm{p}>0.10)$.

For hypothesis 4 , which stated that cultural distance would negatively affect Chinese outward FDI, we obtained mixed results. By measuring the cultural distance using the KogutSingh index (1988), the observed effect is not statistically significant $(\beta=0.08, \mathrm{p}>0.10)$. However, when the cultural distance is proxied by the percentage of ethnic Chinese in the host country, a statistically significant result is obtained $(\beta=0.31, \mathrm{p}<0.05)$. This means that hypothesis 4 can be partially supported.

\section{DISCUSSION AND CONCLUSION}

This chapter aimed to study the influence of various host country factors on the location decisions made by large Chinese firms. We first hypothesized that Chinese MNEs were attracted by host market size. Our results support this view considering absolute host market size, which would coincide with the findings of previous research into Chinese MNEs (Buckley et al., 2007; Bunyaratavej \& Hahn, 2007; Duanmu, 2011; Duanmu \& Guney, 2009; Kolstad \& Wii, 2011; Li \& Wu, 2006).

However, considering host market growth we did not obtain statistical significance. This lack of significance has been also observed in previous papers on Chinese outward FDI (Kang \& Jiang, 2011; Li \& Wu, 2006). Duanmu and Guney (2009) even found that GDP 
growth rate negatively and significantly impacted Chinese outward FDI. They argued that Chinese FDI may be more attracted by established economies, which have passed the phase of economic growth and may in some cases even experience an economic recession. Anyway, it should be pointed out that our findings are influenced by the global economic downturn over the last years covered by our sample.

Regarding the strength of host market supporting institutions, our results did not support the predicted positive effect on the number of Chinese FDIs. Some previous studies on Chinese MNEs found that the managers of Chinese MNEs gave considerable weight to regulations in the host country's institutional framework when deciding to enter that market (Cui \& Jiang, 2009b, 2010).

One possible explanation for this result, which is against initial expectations, may be that although many Chinese companies do not have asset advantages such as technology and branding, they do have a transaction advantage: the ability to manage relationships within a complex environment such as China. This gives them an edge over MNEs from developed countries when it comes to investing in markets with these institutional characteristics (Morck, Yeung \& Zhao, 2008). Therefore, in countries with a weak institutional framework, Chinese MNEs may have an advantage over Western competitors, given that the rules when doing business in China may be more similar to those of these host countries (Malhotra \& Zhu, 2009). One example of this can be found in CNPC's entry in PetroKazakhstan, which had previously been controlled in that country by a Canadian firm.

Our third hypothesis, which established an inverse relationship between political risk in the host country and Chinese outward FDI, is also not supported. This goes against the results of previous studies on Chinese MNEs (Duanmu, 2011; Duanmu \& Guney, 2009). However, we did find empirical evidence in line with our result, suggesting that the risks of the host country do not affect Chinese MNEs in a conventional way. Cui and Jiang (2009a) 
find that country risk does not affect how Chinese MNEs commit FDI resources. Buckley et al. (2007) do not confirm that Chinese outward FDI is negatively associated with high levels of political risk in the host country. Some papers even find that Chinese MNEs tend to invest in countries with higher levels of risk (Bunyaratavej \& Hahn, 2007; Kang \& Jiang, 2011; Malhotra \& Zhu, 2009; Ramasamy et al., 2011).

Several explanations can be found for this result that contradicts the conventional influence of political risk on FDI decisions. Firstly, the size of the FDI may affect the influence of political risk. Thus, when making large investments, Chinese companies can take advantage of the opportunity to acquire cheaper assets in countries with a politically unstable system (Malhotra \& Zhu, 2009). Secondly, Chinese companies may attempt to take advantage of the opportunities presented by high-risk countries, whose markets may not be highly exploited or may even be unknown to large Western MNEs, such as first-mover advantages, less competition or a lower level of consumer sophistication (Bunyaratavej \& Hahn, 2007). Thirdly, the very idiosyncrasy of China's own institutional framework may also go some way to explaining our result (Buckley et al., 2007). Because of imperfections in the Chinese capital market, the cost of capital is very low for Chinese SOEs. Furthermore, because they are conditioned by the institutional influences of the Chinese government, they may not be behaving purely as profit maximizers. Finally, an important part of the Chinese outward FDI has been directed at countries with which China has close political and ideological ties, many of which have a high political risk.

Regarding our fourth hypothesis, which predicted a negative influence of cultural distance on Chinese outward FDI, our results were able to provide partial support. By measuring the cultural distance using the Kogut-Singh index (1988), we did not obtain statistical significance. This result goes against observations made by certain previous studies. For example, using the same measurement tool, $\mathrm{Li}$ and $\mathrm{Wu}$ (2006) found that cultural distance 
had a negative influence on the number of Chinese FDIs in each country, and Kang and Jiang (2011) reported that Chinese firms tended to locate FDI operations in host countries with a smaller cultural distance. Cui and Jiang (2009a, 2009b, 2010) found, albeit using another approach, that cultural barriers also had a negative impact on Chinese companies committing FDI resources.

One possible reason for our result may be that the influence of cultural distance may depend on the Chinese company's objectives. While investments that sought markets might well have been initially aimed at countries in which this distance was smaller, investments that seek know-how have been mainly aimed at developed countries in North America and Europe, which are culturally more distant (Young, Huang \& McDermott, 1996). Also, many Chinese companies do not seem to shy away from cultural distance, perhaps aided by the alliances they have made in China with MNEs from developed countries (Luo \& Tung, 2007).

However, using the proportion of ethnic Chinese in the host country as a measure of cultural proximity, an influence can be observed in line with hypothesis 4 . The proportion of ethnic Chinese in the host country seems to be a significant factor in attracting Chinese outward FDI. This result coincides with findings by Buckley et al. (2007), who offer various explanations for the particular importance of overseas Chinese. The Chinese diaspora has contributed to China's integration into the world economy, thanks in particular to the number of FDIs in China from Singapore, Hong Kong and Taiwan. However, overseas Chinese may also have a significant influence on the choice of host country for Chinese outward FDIs. Contacts and social networks (known in China as guanxi) are one of the essential ingredients for the Chinese when doing business. The presence of overseas Chinese in a certain country may therefore reduce the risks and costs associated with identifying business opportunities by Chinese companies, thus favoring Chinese outward FDI. 
In conclusion, our findings suggest that the location patterns of Chinese MNEs show both conventional and less conventional features. Thus, a larger absolute market size in the host country is an attractive location factor, particularly for Chinese companies looking for markets as part of their international expansion. Moreover, the presence of overseas Chinese in the host country seems to be a factor that helps Chinese companies to overcome the possible cultural barrier.

However, other findings from our work seem to go against the conventional logic that has been observed in location decisions made by MNEs from other, particularly Western, countries. A weak institutional framework in the host country, which makes it more difficult to do business and which involves a high political risk, does not act as a particular disincentive for Chinese MNEs. Furthermore, although we used a conventional measurement that is widely used in the literature on MNEs, we were unable to confirm that cultural distance is an important institutional barrier for Chinese companies.

On the other hand, we have provided new empirical evidence regarding a phenomenon that is acquiring ever-increasing economic importance: the arrival of emerging-market MNEs on the international scene. Even though in recent years more and more studies have focused on Chinese MNEs, given the recent nature of their internationalization process, this research topic has yet to really establish itself. Further research is therefore needed to extend our knowledge of a type of MNE that plays an increasingly relevant role in international business. 


\section{REFERENCES}

Brouthers, K.D. (2002). Institutional, cultural and transaction cost influences on entry mode choice and performance. Journal of International Business Studies, 33(2): 203-221.

Buckley, P,J., Clegg, L.J., Cross, A.R., Liu, X., Voss, H., \& Zheng, P. (2007). The determinants of Chinese foreign direct investment. Journal of International Business Studies, 38(4): 499-518.

Bunyaratavej, K., \& Hahn, E.D. (2007). Outward foreign direct investments from China: Theory and determinants. AIB 2007 Annual Meeting, Indianapolis, IN, June 25-28.

Chen, H., \& Hu, M.Y. (2002). An analysis of entry mode and its impact on performance. International Business Review, 11(2): 193-210.

Cheng, L.K., \& Ma, Z. (2007). China's outward FDI: Past and future. Working paper no. 2007706001E. School of Economics, Renmin University, China.

Child, J., \& Rodrigues, S.B. (2005). The internationalization of Chinese firms: A case for theoretical extension? Management and Organization Review, 1(3): 381-410.

Cui, L., \& Jiang, F. (2009a). FDI entry mode choice of Chinese firms: A strategic behavior perspective. Journal of World Business, 44(4): 434-444.

Cui, L., \& Jiang, F. (2009b). Ownership decisions in Chinese outward FDI: An integrated research framework and research agenda. Asian Business \& Management, 8(3): 301-324.

Cui, L., \& Jiang, F. (2010). Behind ownership decision of Chinese outward FDI: Resources and institutions. Asia Pacific Journal of Management, 27(4): 751-774.

Davies, K. (2010). Outward FDI from China and its policy context. Columbia FDI Profiles. Vale Columbia Center on Sustainable International Investment. http://www.vcc.columbia.edu/

Deng, P. (2004). Outward investment by Chinese MNCs: Motivations and implications. Business Horizons, 47(3): 8-16.

Duanmu, J.L. (2011). Firm heterogeneity and location choice of Chinese Multinational Enterprises (MNEs). Journal of World Business, forthcoming.

Duanmu, J.L., \& Guney, Y. (2009). A panel data analysis of locational determinants of Chinese and Indian outward foreign direct investment. Journal of Asia Business Studies, 3(2): 1-15.

Gugler, P., \& Fetscherin, M. (2010). The role and importance of the Chinese government for Chinese outward foreign direct investments. AIB Insights, 10(4): 12-15. 
Hofstede, G. (1980). Culture's consequences. International differences in work-related values. Newbury Park, CA: Sage Publications.

Hofstede, G. (1991). Cultures and organizations. Software of the mind. London: Mc Graw-Hill.

Hofstede, G., Van Deusen, C.A., Mueller, C.B., Charles, T.A., \& The Business Goals Network (2002). What goals do business leaders pursue? A Study in fifteen countries. Journal of International Business Studies, 33(4): 785-803.

Hong, E., \& Sun, L. (2006). Dynamics of internationalization and outward investment: Chinese corporations' strategies. The China Quarterly, 187: 610-634.

Kang, Y., \& Jiang, F. (2011). FDI location choice of Chinese multinationals in East and Southeast Asia: Traditional economic factors and institutional perspective. Journal of World Business, forthcoming.

Kobrin, S.J. (1979). Political Risk: A review and reconsideration. Journal of International Business Studies, 10(1): $67-80$.

Kogut, B., \& Singh, H. (1988). The effect of national culture on the choice of entry mode. Journal of International Business Studies, 19(3): 411-432.

Kolstad, I. \& Wiig, A. (2011). What determines Chinese outward FDI? Journal of World Business, forthcoming. KPMG (2010). World class aspirations: The perceptions and the reality of China outbound investment. KPMG China. http://www.kpmg.com/cn.

Li, Y., \& Wu, C. (2006). Agglomeration effect, location advantage and location choice of FDI from developing countries: The case of China. AIB 2006 Annual Meeting, Beijing, China, June 23-26.

Luo, Y., \& Tung, R.L. (2007). International expansion of emerging market enterprises: A springboard perspective. Journal of International Business Studies, 38(4): 481-498.

Luo, Y., Xue, Q., \& Han, B. (2010). How emerging market governments promote outward FDI: Experience from China. Journal of World Business, 45(1): 68-79.

Madhok, A. (1997). Cost, value and foreign market entry mode: The transaction and the firm. Strategic Management Journal, 18(1): 39-61.

Malhotra, S., \& Zhu, P.C. (2009). Determinants and valuation impact of cross-border acquisitions by firms from China and India. AIB 2009 Annual Meeting, San Diego, CA, June 27-30.

Mascarenhas, B. (1992). Order of market entry and performance in international markets. Strategic Management Journal, 13(7): 499-510. 
Meyer, K.E., Estrin, S., Bhaumik, S.K., \& Peng, M.W. (2009). Institutions, resources, and entry strategies in emerging economies. Strategic Management Journal, 30(1): 61-80.

MOFCOM (2010). 2009 Statistical Bulletin of China's Outward Foreign Direct Investment. Beijing: Ministry of Commerce (MOFCOM), Department of Outward Investment and Economic Cooperation, http://english.mofcom.gov.cn.

Morck, R., Yeung, B., \& Zhao, M. (2008). Perspectives on China's outward foreign direct investment. Journal of International Business Studies, 39(3): 337-350.

Neter, J., Wasserman, W., \& Kutner, M.H. (1985). Applied linear statistical models: Regression, analysis of variance and experimental designs. 2nd edition. Homewood: Richard D. Irwin, Inc.

Ohio University (2010). Distribution of the ethnic Chinese population around the world. Ohio University Library and the Shao Center. http://cicdatabank.library.ohiou.edu/opac/population.php.

Pak, Y.S., \& Park, Y.R. (2004). Global ownership strategy of Japanese multinational enterprises: A test of internalization theory. Management International Review, 44(1): 3-21.

Pangarkar, N., \& Yuan, L. (2009). Location in internationalization strategy: Determinants and consequences. Multinational Business Review, 17(2): 37-68.

Peng, M.W., \& Delios, A. (2006). What determines the scope of the firm over time and around the world? An Asia Pacific perspective. Asia Pacific Journal of Management, 23(4): 385-405.

Peng, M.W., Wang, D.Y.L., \& Jiang, Y. (2008). An institution-based view of international business strategy: A focus on emerging economies. Journal of International Business Studies, 39(5): 920-936.

PRS (2010). International Country Risk Guide (ICRG). The Political Risk Services Group. http://www.prsgroup.com/.

Ramasamy, B., Yeung, M., \& Laforet, S. (2011). China's outward foreign direct investment: Location choice and firm ownership. Journal of World Business, forthcoming.

Randoy, T., \& Dibrell, C.C. (2002). How and why Norwegian MNCs commit resources abroad: Beyond choice of entry mode. Management International Review, 42(2): 119-140.

Robock, S.H. (1971). Political risk: identification and assessment. Columbia Journal of World Business, JulyAugust: 6-20.

Shoham, A. \& Rosenboim, M. (2009). China's new approach to ODI in Africa: A model for a government seeking natural resources. In I. Alon et al. (Eds.), China rules. Globalization and political transformation: 216-230. Hampshire, UK: Palgrave MacMillan. 
Simon, J.D. (1984). A theoretical perspective on political risk. Journal of International Business Studies, 15(3): 123-143.

UN Statistics Division (2010). National Accounts Main Aggregates Database. United Nations Statistics Division. http://unstats.un.org/.

UNCTAD (2010). World Investment Report 2010. Investing in a low-carbon economy. New York and Geneva: United Nations Conference on Trade and Development.

Wong, J., \& Chan, S. (2003). China's outward direct investment: Expanding worldwide. China: An International Journal, 1(2): 273-301.

World Bank (2010). Ease of doing business rank. http://www.doingbusiness.org/rankings.

Wu, F. (2007). Corporate China goes global. In H. Wai-Chung Yeung (Ed.), Handbook of research on Asian business: 445-465. Cheltenham, UK: Edward Elgar Publishing.

Wu, F., \& Sia, Y.H. (2002). China's rising investment in Southeast Asia: Trends and outlook. Journal of Asian Business, 18(2): 41-61.

Young, S., Huang, C.H., \& McDermott, M. (1996). Internationalization and competitive catch-up processes: Case study evidence on Chinese multinational enterprises. Management International Review, 36(4): 295 314.

Yu, C.M.J. (1990). The experience effect and foreign direct investment. Weltwirtschaftliches Archiv, 126(4): 561-580.

Yuan, L., \& Pangarkar, N. (2010). Inertia versus mimicry in location choices by Chinese multinationals. International Marketing Review, 27(3): 295-315.

Zhang, H.Y., \& Van den Bulcke, D. (1996). International management strategies of Chinese multinational firms. In J. Child \& Y. Lu (Eds.), Management issues in China in the 1990s: International enterprises: 141-164. London: Routledge.

Zheng, P. (2009). A comparison of FDI determinants in China and India. Thunderbird International Business Review, 51(3): 263-279. 